\title{
Rationale as an Innovative Learning Application to Improve Students' Critical Thinking in Argumentative Writing
}

\author{
Nova Alfi Laili Rahmah'1, Ahmad Munir², Syafi'ul Anam³ \\ ${ }^{1}$ English Education Department, Language And Literature Education Study, Postgraduate of State University of Surabaya, 60213, Indonesia \\ a nova.17070835051@mhs.unesa.ac.id, b ahmad.munir@unesa.ac.id, c syafiul.anam@unesa.ac.id \\ ${ }^{*}$ Corresponding Author \\ Whatsapp number [ +6285733339322]
}

How to Cite : Rahmah, N., A., L., Munir, A., Anam, S. (2019). Rationale as an Innovative Learning Application to Improve Students' Critical Thinking in Argumentative Writing. International Journal for Educational and Vocational Studies, 1 (7), 744-749

\section{ARTICLE HISTORY}

Received: 13 July 2019

Revised: 23 August 2019

Accepted: 20 October 2019

\section{KEYWORDS}

Rationale Software;

Critical Thinking;

Tertiary Students;

Argumentative Text;

\begin{abstract}
This study is about the effect of rationale application usage as innovative learning application to help the students being critical thinker in writing argumentative text. It was attempted to investigate (1) whether there is any significant difference between students reasoning ability, (2) whether there is any significant difference between students structuring ability, and (3) whether there is any significant difference between students analyzing ability who are taught by using rationale application as found in their argumentative writing and those who are not taught without using rationale. To do so, a quasi-experimental designed was administered to a sample of University students $(\mathrm{N}=50)$. In order to answer the research questions, the data are analyzed by using independent sample t-test. SPSS 21 is used to do those statistical analysis. In conclusion, the findings showed that rationale application can be chosen as an alternative media of improving critical thinking in argumentative writing. It was proved by the findings of the study that bring us to the point that there was a significant difference on the students' critical thinking in some aspects (reasoning, structuring and analyzing ability) as found in their argumentative writing between learners in experimental and control group. Learners who are given rationale application treatment achieve higher than those who are given conventional method.
\end{abstract}

This is an open access article under the CC-BY-SA license.

\section{INTRODUCTION}

In university context, students are expected to be able to report research academically. The report can be in the form of essay, paper or theses. Through that way, university students are expected not only able to conduct a valuable research academic way but also into a systematic writing product to contribute in academic literature. Because of this reason, critical thinking is needed in order to achieve it. Cotrell (2005) defines critical thinking is a complex process of developing a wide range of personal qualities, skills and attitudes. She explains critical thinking skill will improve with practice and with a proper sense of what is required. Sometimes, it may change behaviors such as paying attention to detail or taking a more uncertain to what they see, hear and read. Critical thinking is important, it can help to shape the students' attitude and skill. Thinking critically will also influence on the way they think in understanding what is relevant and what is not to be more accurate and specific.

Critical thinking is strictly tied in academic writing, it is an expression of the authors' ability to understand and analyze the ideas, evaluate and synthesize the arguments- in a variety of sources before making any conclusions, and then presenting them clearly to the reader. Practicing argumentative writing is tightened to the development of critical thinking skills (Twardy, 2004; Dariman, 2019).

However, there are some problems which is faced from the teacher and students in teaching learning process. (Sadli, 2002) stated there is little guidance to encourage critical thinking skills and students get difficulty in providing a supporting reason. As a result, they get stuck in the process of writing without being critical thinker. Moreover, (Samanhudi, 2011) in his study showed that the students need more guidance to grasp some critical thinking standards in such mentioning credible source and constructing argument systematically, following a line of reasoning consistently to a conclusion. Therefore, there is a need of designing a powerful writing environment for EFL students to allow them practicing their argumentation to develop their critical thinking skills effectively. Here, the researcher proposed Rationale application would be an effective way to enhance general critical thinking skills (Twardy,2003;Dariman, 2019; Sukariasih et al., 2019). 
Gelder (2007) stated that Rationale is considered as one of critical thinking program to represent better arguments for the following reasons: 1) It is designed for argument mapping to present reasoning which provides the way of improving critical thinking skills 2) This application can be used to improve the students' ability in processing information and 3) this application provides a usable for semi-formal reasoning. That is why, Rationale as one of the argument mappings application which can be used facilitating students to visualize their arguments in order to produce an organized argumentative essay.

Based on Gelder (2007) Critical thinking with rationale comprises six clusters, (1) Grouping, it is about how the students' ability to organize their idea. (2) Reasoning deals with how the students support a claim and structure. (3) Structuring is about the students' ability to analyze claims and uncover assumptions. (4) Analyzing is the students' ability to identify and assess sources of information. (5) Evaluating means the students' ability to evaluate arguments (6) Deliberating deals with students' ability to decide whether the claims based on relevant consideration or not.

In this study, the researcher only focuses on three competencies because based on problem identified by Elsegood (2007) is most of students were unable to see how a writer unable to follow the flow of logical reasoning, they lack of understand the link between supporting and opposing (counter) arguments which belong to three aspect of critical thinking: reasoning, structuring and evaluating.

In response to this, the researcher formulate a question "Is there any significant difference in developing critical thinking aspect (reasoning, structuring, and analyzing ability) between learners who are taught using rationale application as found in their argumentative writing and those who are not taught using rationale?".

Table 1. Research schedule

\section{METHODS}

The researcher used quasi experimental design in order to investigate the significant difference between aspect of students' critical thinking that are taught using Rationale and that of students without using Rationale. To determine the group, the researcher took classes that have been selected as sample of research. The test is conducted in Unusa and the researcher needs another lecturer to help her in distributing and collecting the test sheets. In finding the sample, the researcher took one class, the number of one class is 25 students which means the researcher will find 50 students as the sample.

In this study, the research instrument designed to collect the data. Those are pre-test, post-test and scoring rubric. The pre-test was administered to obtain the subject score before giving treatment and the post-test to obtain after giving a treatment (the implementation of rationale). The pre-test and post-test consist of same topic to compose a short essay.

The following are the procedures of the research which is done by the researcher. First, the researcher conducted a pre-test by giving topic of argumentative writing on April 16th, 2019. It administered one week before receiving the treatment. The topic which was given was about "youtuber". The students are expected to write at least 250 words. Then, the researcher assessed the students' writing by analyzing aspects of critical thinking in argumentative writing. The aspects can be analyzed through scoring rubric to know how the students' critical thinking of each aspect in argumentative writing before the treatment.

After giving the pre-test, the experimental group were taught using Rational, while the control group was taught without using Rational. The schedule of research will be shown below:

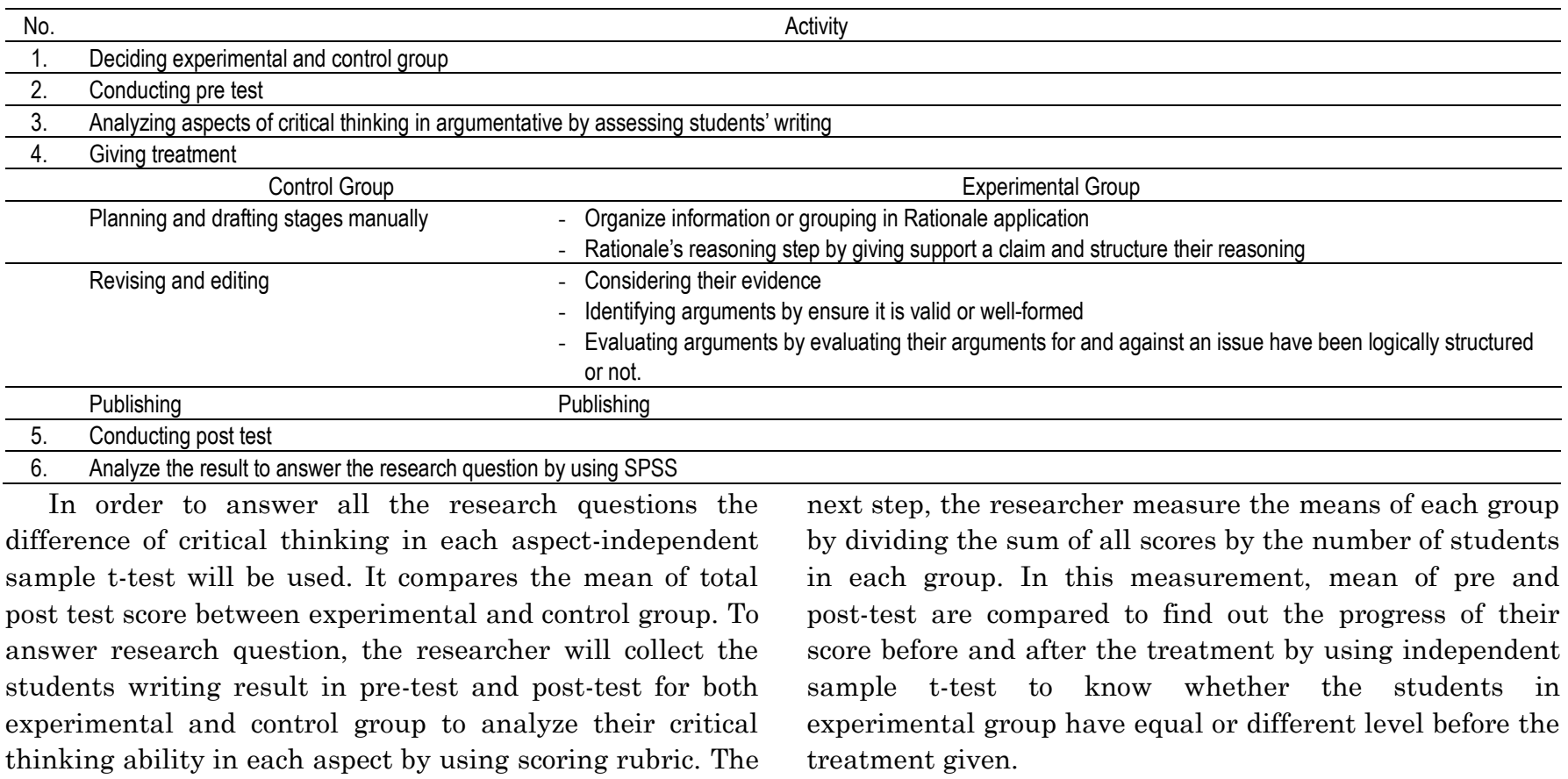


Before independent sample t-test are done, the data of normality and homogeneity are important to be tested. Test of data normality using SPSS is applied. After analyzing normality, the analysis of homogeneity is needed to know whether the learners in both groups have equal competence or not.

To draw a conclusion using the output of independent $\mathrm{t}$-test, if $\mathrm{p}$-value is greater than 0,05 , null hypothesis is rejected so alternative hypothesis is accepted (Larson Hall, 2010). If alternative hypothesis is accepted, it means that the difference of means score between experimental and control group is greater enough or significant. In other words, the improvement of students score in each aspect of critical thinking in argumentative writing is the significance effect of the use rational application. Otherwise, if $\mathrm{p}$-value is less than 0,05 , null hypothesis is accepted which means there is no significance differences of students taught using rational application and using lecturing method.

\section{RESULTS AND DISCUSSION}

\subsection{The Students' Reasoning Ability as Found in Their Argumentative Writing by using Rationale Application}

The term reasoning ability deals with the students' ability to support a claim and structure their reasoning. Sometimes, many students provide opinions but rarely give supporting reasons for their view. Research question 1 deals with the significant difference on the reasoning ability of learners taught using Rationale application and those taught using conventional method. The independent-sample t-test was used to answer the first research question on finding out whether there was a significant difference on the scores between the two compared groups (experimental and control group). The comparison of the results of the test of the experimental and control groups is portrayed in the following table 2 .

Table 2. Comparison of the Post-test Reasoning ability Scores from the Experimental and Control Groups

\begin{tabular}{cccccccc}
\hline Score & Group & Mean & $\mathrm{N}$ & $\mathrm{SD}$ & $\mathrm{T}$ & $\mathrm{p}$-value & Analysis \\
\hline \multirow{2}{*}{$\begin{array}{c}\text { Post-test reasoning } \\
\text { ability }\end{array}$} & Experimental (by using Rationale app.) & 31.32 & 25 & 1.314 & 23.12 & 0.000 & \multirow{2}{*}{ Significant } \\
\cline { 2 - 6 } & Control (manually) & 22.48 & 25 & 1.388 & 23.12 & & \\
\hline
\end{tabular}

From the table, it shows that there was a significant difference in the post test score for experimental $(\mathrm{M}=31.32$, $\mathrm{SD}=1.314)$ and control group $(\mathrm{M}=22.48, \quad \mathrm{SD}=1.388)$ conditions $\mathrm{t}(48)=23.12, \mathrm{p}=0.000$. The $\mathrm{p}$-value is smaller than the 0.05 level of significance. In other words, there was an effect on the implementation of rationale application. The students which is taught using it reached better score than those taught manually.

Through this application, the students are facilitated to support their responses and to consider different opinions which is done in the planning stage of writing. So that students understand the relationship between the statements. This result was in line with the way proposed by Gelder (2009) stated that Rationale is considered as one of critical thinking program to represent better arguments.

With regard to the first research question, the result of this study indicated that rationale application was also beneficial to develop critical thinking in a reasoning aspect. It was figured out by the result of the post-test showing that the students established an increase their reasoning throughout the treatment. The data from the first research

Table 3. Comparison of the Post-test Structuring ability Scores from the Experimental and Control Groups

\begin{tabular}{|c|c|c|c|c|c|c|c|}
\hline Score & Group & Mean & $\mathrm{N}$ & SD & $T$ & $p$-value & Analysis \\
\hline \multirow{2}{*}{$\begin{array}{l}\text { Post-test reasoning } \\
\text { ability }\end{array}$} & Experimental (by using Rationale app.) & 22.88 & 25 & 1.452 & 14.33 & 0.000 & Significant \\
\hline & Control (manually) & 17.04 & 25 & 1.428 & 14.33 & & \\
\hline
\end{tabular}

The result of t-test on the students' post-test scores showed that the result is same in the score of post-test treatment group $(\mathrm{M}=22.88, \mathrm{SD}=17.04)$ and manual group $(\mathrm{M}=17.04$, $\mathrm{SD}=1.42)$ condition $\mathrm{t}(48)=14.33, \mathrm{p}=0.000$. As the $\mathrm{p}$-value was smaller than 0.05 , it can be concluded that student's structuring ability is better when they were taught using rationale application. question 1 implies that the mean score of the students from the experimental group was higher than the scores of the students from the control group.

Another evidence to support the statistical data was that the result of t-test (independent sample) reports from Dwyer (2012) that there was a significant difference on post-testing compared with pre-testing on overall CT ability and CT sub-scales which can be said that students who is taught using argument mapping achieved better score than those taught using conventional method.

\subsection{The Students' Structuring Ability as Found in Their Argumentative Writing by using Rationale Application}

Structuring ability involves the students' ability to analyze claims and uncover assumptions. Research question 2 was answered by using independent-sample t-test to find the effect of the treatment in their structuring ability. The post-test score of structuring ability between the experimental and control group was analyzed by means of SPSS 21.
As technology becomes part of students' everyday life, rationale application can be chosen as the alternative way to help the students able to present arguments (opening, closing and all major of support) orderly in paragraph and to demonstrate coherence and cohesion by using of transitional devices. These facts were related with the statement of Gelder (2009) stated that Rationale 
application can be used by the teacher as a tool to help students build map arguments properly because there is a table for the argument topic at the top level then followed by a conjunction 'because' as supporting claim and 'but' as the objection. Thus, by practicing argument mapping through this media the students are forced to be more structured in expressing their idea critically. This result was also in line with Wegerif and Dawes (2004) theory that "computers can most effectively support meaningful learning and knowledge construction in higher education as cognitive amplification tools for reflecting on what students have learned and what they know." To sum up, the implementation of rationale application can enhance students' critical ability especially in the students' structuring ability. The current study has shown that students taught using rationale application had better in

Table 4. Comparison of the Post-test Analyzing ability Scores from the Experimental and Control Groups

\begin{tabular}{c|c|c|c|c|c|c|c}
\hline Score & Group & Mean & $\mathrm{N}$ & $\mathrm{SD}$ & $\mathrm{T}$ & $\mathrm{p}$-value & Analysis \\
\hline \multirow{2}{*}{$\begin{array}{c}\text { Post-test reasoning } \\
\text { ability }\end{array}$} & Experimental (by using Rationale app.) & 10.28 & 25 & 0.613 & 8.13 & 0.000 & \multirow{2}{*}{ Significant } \\
\cline { 2 - 6 } & Control (manually) & 8.72 & 25 & 0.872 & 8.13 & & \\
\hline
\end{tabular}

The result of t-test on the students' post-test scores of analyzing ability showed the score for treatment by using rationale application $(\mathrm{M}=10.28, \mathrm{SD}=0.613)$ and manually group $(\mathrm{M}=8.72, \mathrm{SD}=0.872)$, condition $\mathrm{t}(48)=8.13, \mathrm{P}=0.000$. It can be seen that rationale application affected the students' analyzing ability.

The result gives evidence that rationale application may be applied to improve the performance of analyzing ability because they are able to achieve some sub skills in the analyzing ability such as providing well-structured argument, other research and counter argument. Baron (1988) stated argument-counterargument integration is important because it is a central aspect of critical thinking. He viewed thinking as active open minded thinking which considers counterarguments.

This result was in line with the study by Okumus (2012) the students can enhance their argumentation skills through argumentation mapping model. They were able to use rebuttals effectively and related claims and reason. They could also use support opinion and data in their arguments. Regardless the difference of the tools used in the treatment, both of these studies has shared the same positive results.

In addition, the successful result of this study can be used to solve the problem from Elsegood (2007) research. His research showed that most of students were unable to see how built up their case because they were unable to follow the flow of logical reasoning. They are difficult to present a clear position in their writing like difficulties in providing a supporting reason and lack of understand the link between supporting and counter arguments. Whereas, Nusbaum (2007) stated the persuasiveness of the argument can increase if the writer able to consider counterarguments to their own arguments and integrate their arguments and the counterarguments into an overall final position. presenting their argument orderly and demonstrate the transactional devices (i.e on the other hand, however, moreover, etc.) properly. The treatment given in the experimental group proved that rationale application influence the students' achievement in structuring ability of writing argumentative essay.

\subsection{The Students' Analyzing Ability as Found in Their Argumentative Writing by using Rationale Application}

Analyzing ability deals with the students' ability to identify and assess sources of information. In addressing the third research question, the comparison of structuring ability scores from the experimental and control groups was presented in table 4.

In short, the students' difficulties in forming argument can be decreased by using rationale application. Since this application provides table for the argument topic at the top level then followed by reason, objection and rebuttal table that should be filled by the students. Gelder (2009).

\section{CONCLUSION}

The current study was aimed at investigating the effect of Rationale application usage on students' critical thinking in argumentative writing. A quasi-experimental design was selected to seek the effect of the treatments and the conclusions described as follow:

The first finding was in line with (Dwyer, 2012) research that there was a significant difference on post-testing compared with pre-testing. So, students who is taught using argument mapping achieved better score than those taught using conventional method. The second finding showed that there was a significant difference in the structuring aspect, the mean of the post-test have significantly different score and the third finding showed that rationale application can enhance their argumentation skills through argumentation mapping model. They were able to use rebuttals effectively and related claims and reason.

In general, the use of rationale application was proved to be a good choice in promoting the students' critical thinking performance especially in writing argumentative text. This concept was in line with (Alvarez-Ortiz, 2007), (Gelder, 2009) that the use of Argument Mapping as a strategy may enhance overall levels of critical thinking.

It was also in line with (Wegerif \& Dawes, 2004) theory that "computers can most effectively support meaningful learning and knowledge construction in higher education as cognitive amplification tools for reflecting on what students have learned and what they know." 


\section{REFERENCES}

Akyüz, H., \& Samsa, S. (2009). The effects of blended learning environment on the critical thinking skills of students. Procedia - Social and Behavioral Sciences 1 (2), 1744-1748.

Alfianti, Prihatin, J., \& Aprilya, S. (2013). The influence of cooperative learning model of reciprocal teaching with example non example technique on critical thinking and students' learning outcome. Pancaran Pendidikan, 2(3), 187-200.

Alvarez-Ortiz, C. (2007). Does philosophy improve critical thinking skills? Australia: University of Melbourne.

Alwasilah, C. (2001). Language, Culture and Education. Bandung: Andira.

Ary, D., Jacobs, L. C., \& Sorensen, C. (2010). Introduction to Research in Education. Belmont: Wadsworth, Cengage Learning.

Ary, D., Jacobs, L. C., \& Sorensen, C. K. (2010). Introduction to Research in Education. Belmont: Wadsworth, Cengage Learning.

Babbie, E. R. (2011). Qualitative research: General principles. Research methods for social work, 436-455.

Barbara, D., \& Peterson, F. (2009). De La HarpeThe theory and practice of teaching with technology in today's colleges and universities. Information technology and constructivism in higher education: Progressive learning frameworks, 27-42.

Baron, J. (1988). Thinking and deciding. New York: Cambridge University Press.

Bloom, B. S. (1994). Reflections on the development and use of the taxonomy. Yearbook: National Society for the Study of Education, 92(2), 1-8.

Boyer, E. L. (1983). High school: A report on secondary education in America. New York: Harper \& Row.

Brown, H. D. (2001). Teaching by principle. . San Fransisco: San Fransisco State university.

Brown, H. D. (2004). Language Assessment: Principles and Classroom Practices. New York: Pearson Education .

Cohen, L., Manion, L., \& Morrison, K. (2007). Research Methods in Education. New York: Routledge.

Cotrell, S. (2005). Critical thinking skills: developing effective analysis and arguments. New York: Palgrave Macmillan.

Creswell, J. (2013). Research design: Qualitative, quantitative, and mixed methods approaches. United States: Sage publications.

Dariman, K. (2019). Students' Creative Thinking With 4'R Applications in Procedure Text Project Based Learning. International Journal for Educational and Vocational Studies, 1(1), 15-20.

Davies, W. M. (2009). Computer-assisted argument mapping: a rationale approach. Higher Education, 58(6), 799 .
Dawes, L., \& Wegerif, R. (2004). Thinking and learning with ICT: Raising achievement in primary classrooms. Rouletdge.

De la Harpe B, P. F. (2009). The theory and practice of teaching with technology in today's colleges and universities. USA: In Payne CR (Ed).

Dewey, J. (1910). How we think. Boston: MA: DC Heath.

Dwyer, C. P. (2011). The promotion of critical thinking skills through argument mapping. 97-122.

Dwyer, C. P. (2012). An evaluation of argument mapping as a method of enhancing critical thinking performance in e-learning environments. Springer , 219-244.

Eftekhari, M. (2016). Computer-aided argument mapping in an EFL setting: does technology precede traditional paper and pencil approach in developing critical thinking? Educational Technology Research and Development V. 64 (2), 339-357.

Elsegood, S. (2007). Teaching critical thinking in an English for academic purpose program using a 'claims and supports' approach. First Year in Higher Education Conference Vol. 1, 1-10.

Ennis, C. (1991). Discrete thinking skills in two teachers' physical education classes. The Elementary School Journal, 91, 473-486.

Facione, P. A. (1998). Critical thinking: What it is and why it counts. California: Academic Press.

Fahim, M. B. (2012). Effects of critical thinking strategy training on male/female EFL learners' reading comprehension. English Language Teaching, 5(1), 140.

Garson, D. (2012). Significance Testing: Parametric and Non-parametric. North Carolina: Statistical Associates Publishers.

Gelder, T. V. (2009, November 17). Argument mapping. Retrieved from Encyclopedia: http://timvangelder.com/2009/02/17/what-is-argumentmapping

Hager, P. e. (2003). Teaching critical thinking in undergraduate science courses. Science \& Education, 12(3), 303-313.

Hyland, K. (1990). A genre description of the argumentative essay. relc Journal, 21(1), 66-78.

Imaniar, F. (2018). Critical Thinking in the Teaching of EFL Academic Writing. Surabaya: UNESA.

Krathwohl, D. (2002). A Revision of Bloom's Taxonomy: An Overview. Theory Into Practice. Theory into practice, 41(4), 212-218.

Kuek , M. C. (2010, Decemeber 15). Developing critical thinking skills through integrative teaching of reading and writing in the L2 writing classroom. London: Newcastle University. Retrieved from Newcastle University: http://hdl.handle.net/10443/1063

Lavelle, E., Smith, J., \& O'Ryan, L. (2002). The writing approaches of secondary Students. British Journal of Educational Psychology, 72 (2), 399-418. 
Leaver, B., Ehrman, M., \& Shekhtman, B. (2005). Achieving success in second language acquisition. England: Cambridge University Press.

Lewis, A. (2001). The issue of perception: some educational implications. Educare, 30(1), 272-288.

Masduqi, H. (2011). Critical thinking skills and meaning in English language teaching. TEFLIN Journal, 22(2), 185-200.

McPeck, J. E. (1990). Critical thinking and subject specificity: A reply to Ennis. Educational Researcher, 19(4), 10-12.

Murris, K. (2014). Corporal punishment and the pain provoked by the community of enquiry pedagogy in the university classroom. Africa Education Review, 11(2), 219-235.

Nussbaum, E. M. (2007). Promoting ArgumentCounterargument Integration in Students' Writing. The Journal of Experimental Education, 76(1), 59-92.

Okumus, S. (2012). The effects of argumentation model on students' achievement and argumentation skills. Procedia-Social and Behavioral Sciences , 457-461.

Oshima, A., Hogue, A., \& Lê, H. L. (2006). Writing academic english. NewYork: Pearson.

Oshima, Alice; Hogue, Ann. (2006). Writing academic english. London: Pearson/Longman.

Pallant, J. (2013). SPSS survival manual. United Kingdom: McGraw-Hill Education .

Paul Stapleton. (2001). Assessing critical thinking in the writing of Japanese university students: Insights about assumptions and content familiarity. Written communication, 18(4), 506-548.

Paul, R. (1995). Critical thinking: How to prepare students for a rapidly changing world.

Reichenbach, B. R. (2001, December 12). Introduction to Critical Thinking. Retrieved from philpapers: https://philpapers.org/go.pl?id=REIITC-2\&proxyId=\&u =http $\% 3 \mathrm{~A} \% 2 \mathrm{~F} \% 2 \mathrm{Fdx}$.doi.org $\% 2 \mathrm{~F} 10.5840 \% 2$ Finquiryct news 19905139

Richards, K. (2009). Trends in qualitative research in language teaching since 2000. Language teaching, 42(2), 147-180.

Sadli, S. (2002). Feminism in Indonesia in an international context. Popline Journal, 11(2), 80-91.

Samanhudi, U. (2018). Researching Students' Critical Thinking in Argumentative Texts. LEKSIKA Journal, 5(2), 11-16.

Saxton, E., Belanger, S., \& Becker., W. (2012). The Critical Thinking Analytic Rubric (CTAR): Investigating intra-rater and inter-rater reliability of a scoring mechanism for critical thinking performance assessments. Assessing Writing, 17(4), 251-270.

Sosniak, L. (1994). Bloom's taxonomy. Chicago: L. W. Anderson (Ed.) Univ. Chicago Press. writing of Japanese university students: Insights about assumptions and content familiarity. Written communication, 18(4), 506-548.

Sukariasih, L., Erniwati, E., \& Salim, A. (2019). Development of Interactive Multimedia on Science Learning Based Adobe Flash CS6. International Journal for Educational and Vocational Studies, 1(4), 322-329.

Twardy, C. (2004). Argument maps improve critical thinking." Teaching Philosophy. Teaching Philosophy, 27(2), 95-116.

Wegerif, R., \& Dawes, L. (2004). Thinking and Learning with ICT. New York: Routledge.

White, R. V. (1995). New Ways in Teaching Writing. New Ways in TESOL Series: Innovative Classroom Techniques. . 1600 Cameron Street, Suite 300, Alexandria, VA 22314.: TESOL.

Stapleton, P. (2001). Assessing critical thinking in the 